\title{
BIOCHEMICAL POLYMORPHISMS AND GENETIC RELATIONSHIPS BETWEEN BRAZILIAN AND FOREIGN BREEDS OF PIGS REARED IN BRAZIL
}

\author{
POLIMORFISMOS BIOQUÍMICOS E O RELACIONAMENTO GENÉTICO ENTRE \\ RAÇAS SUÍNAS BRASILEIRAS E ESTRANGEIRAS CRIADAS NO BRASIL
}

\author{
Cláudia Helena Tagliaro ${ }^{1}$ Maria Helena Lartigau Pereira Franco ${ }^{2}$ Maria Paula Cruz Schneider $^{3}$ \\ Benito Guimarães de Brito ${ }^{4}$ Antonio Stockler Barbosa ${ }^{5}$
}

\section{SUMMARY}

The genetic variability of 14 protein systems encoded by 15 structural loci was investigated in blood samples of Piau and Caruncho pig breeds. The results were compared with those obtained previously for samples of Landrace, Large White, Duroc and Mouro. The degree of genetic variability obtained for Piau (He=0.114) was similar to that estimated for other breeds reared in Brazil (Landrace, He=0.116; Large White, $\mathrm{He}=0.119 ;$ Duroc, 0.095; Mouro, He= 0.130). Caruncho showed the lowest variability $(\mathrm{He}=0.056)$. The gene frequencies at the polymorphic loci were used to evaluate the usefulness of these systems for paternity testing and the combined probabilities of paternity exclusion were estimated at $58 \%$ for the Piau and $36 \%$ for the Caruncho breed. Analysis of genetic distances revealed that the greatest similarity observed was between Piau and Landrace $(D=0.042)$. Caruncho showed the greatest divergence among all breeds compared and the distances between this breed and others range from 0.107 (with Landrace) to 0.176 (with Duroc). The tree constructed by UPGMA and Rogers' Distance gave a topology in which Piau and Mouro joined with the European breeds (Landrace and Large White) whereas Caruncho was separated from all the other breeds. The results of the analysis of the Caruncho samples should be interpreted with caution since the number of animals studied was small.

Key words: swine, protein polymorphisms, genetic relationships.

RESUMO

Foi investigada a variabilidade genética de 14 sistemas protéicos codificados por 15 locos estruturais em amostras de sangue de suínos das raças Piau e Caruncho. Os resultados foram comparados com àqueles obtidos previamente para amostras de Landrace, Large White, Duroc e Mouro. O grau de variabilidade genética obtida para Piau $(\mathrm{He}=0,114)$ foi similar àquelas estimadas para outras raças criadas no Brasil (Landrace, $\mathrm{He}=0,116$; Large White, He=0,119; Duroc, 0,095; Mouro, He= 0,130). Caruncho apresentou a menor variabilidade $(\mathrm{He}=0,056)$. A partir das freqüências gênicas dos locos polimórficos, foi calculada a eficiência de cada sistema para testes de paternidade $e$ as probabilidades combinadas de exclusão de paternidade foram estimadas em 58\% para Piau e 36\% para Caruncho. Análises das distâncias genéticas revelaram que a raça mais próxima da Piau foi a Landrace $(D=0,042)$. Caruncho apresentou as maiores divergências em relação a todas as raças comparadas, que variaram de 0,107 (com Landrace) a 0,176 (com Duroc). A árvore construída através de UPGMA e Distância de Rogers mostrou uma topologia na qual Piau e Mouro se uniram as raças Européias (Landrace e Large White), e Caruncho está separado de todas as demais raças. Os resultados das análises das amostras de Caruncho devem ser interpretados com cautela, uma vez que o número de animais estudados foi pequeno.

Palavras-chave: suínos, polimorfismo protéico, relacionamento genético.

\section{INTRODUCTION}

Brazilian farmers introduced methods of improving swine herds at the beginning of the 20th century. The origins of the Piau, Caruncho and

\footnotetext{
${ }^{1}$ Veterinarian and Geneticist, PhD, Laboratório de Biologia Molecular, Universidade Federal do Pará, Alameda Leandro Ribeiro, s/n, Bragança, 68600-600, Belém, PA, Brazil. E-mail: tagliaro@ufpa.br. Author for correspondence.

${ }^{2}$ Geneticist, PhD, Departamento de Genética, Instituto de Biociências, Universidade Federal do Rio Grande do Sul, Porto Alegre, RS. ${ }^{3}$ Geneticist, PhD, Departamento de Genética, Centro de Ciências Biológicas, Universidade Federal do Pará, Belém, PA.

${ }^{4}$ Veterinarian, MSc., Departamento de Medicina Veterinária Preventiva, Faculdade de Medicina Veterinária, Universidade Estadual de Londrina, PR.

${ }^{5}$ Veterinarian, PhD., Depto de Zootecnia, Escola de Veterinária, Universidade Federal de Minas Gerais, Belo Horizonte, MG (retired). Recebido para publicação em 06.04.98. Aprovado em 02.09.98
} 
Mouro Brazilian breeds of pig are unknown although they have been developed and raised in Brazil for more than 50 years. It is known that the first pigs were brought to Brazil by Portuguese colonists who introduced animals from the Iberian region but African and Dutch stock may have also been introduced (BARRETO, 1986). Landrace, Large White and Duroc are the most common commercial breeds raised in Brazil today and were developed in Europe and North America for meat production. On the other hand, Caruncho, Piau and Mouro were genetically improved mainly for the production of animal fat. For this reason the Brazilian breeds have a more rounded body whereas the imported foreign breeds are characterized by longer and more muscular bodies (CAVALCANTI, 1984).

In this study are included data from previous studies of Landrace, Large White, Duroc and Mouro breeds (TAGLIARO et al., 1993; 1995). The present study examines protein phenotypes from blood samples of Caruncho and Piau breeds. Protein polymorphisms have been used to investigate the levels of genetic variability exhibited by different breeds, to characterize populations, and to verify the relationships between them (OISHI \& TOMITA, 1976; OISHI et al., 1980; TANAKA et al., 1983; VAN ZEVEREN et al., 1990). The gene frequencies of various polymorphic biochemical loci can also be used for paternity testing (OISHI \& ABE, 1970).

The objectives of the present study were to: a) verify the gene frequencies at 15 protein loci in samples of Piau and Caruncho and compare the results with data obtained previously for other breeds; b) estimate the degree of genetic variability; c) evaluate the usefulness of protein polymorphisms for paternity testing; and d) analyse the genetic relationships between the Piau and Caruncho samples and other pig breeds reared in Brazil (TAGLIARO et al., 1993; 1995).

\section{MATERIAL AND METHODS}

Samples of blood were collected from 57 Piau and 7 Caruncho pigs from different regions of Brazil. All the Caruncho samples were collected at the "Instituto Agronômico do Paraná" Experimental Station (IAPAR), in Pato Branco (state of Paraná). Piau samples were collected from three different regions: 36 females from "Professor Hélio Barbosa" Experimental Farm in the municipality of Igarapé (state of Minas Gerais); 2 males and 12 females from the "Companhia do Desenvolvimento Agropecuário do Paraná", in Cândido de Abreu (state of Paraná); and 1 male and 6 females from the
"Instituto Agronômico do Paraná" Experimental Station (IAPAR), in Pato Branco (state of Paraná). The animals were not related.

Genetic variation was assayed by horizontal starch/agarose gel electrophoresis at 15 structural loci: hemopexin (Hpx), amylase 1 and 2 (Amy1 and Amy2), transferrin (Tf), ceruloplasmin (Cp), phosphogluconate dehydrogenase (Pgd), phosphohexose isomerase (Phi), esterase D (EsD), malate dehydrogenase (Mdh), isocitrate dehydrogenase (Idh), superoxide dismutase (Sod), acid phosphatase (Acp), glyoxalase I (GloI), albumin (Al) and hemoglobin ( $\mathrm{Hb})$. Electrophoresis and protein staining described in the literature were used in the present study as follows: Hpx, Amyl and Amy2 (KRISTJANSSON,1963); Tf and Cp (OISHI \& TOMITA;1976); Pgd and Phi (GAHNE \& JUNEJA, 1985); EsD (SPENCER et al., 1964); Mdh, Idh, Sod and Acp (HARRIS \& HOPKINSON; 1976); GloI (FRANCO et al., 1986); Al (TUCKER, 1968); and $\mathrm{Hb}$ (NAOUM, 1987).

Allele frequencies were calculated using the gene counting method and Hardy-Weinberg equilibrium was verified either by the classic chisquared $\left(\chi^{2}\right)$ test or the method described by SMITH (1986) for small samples. The $\chi^{2}$ test with Yate's correction was used to estimate the homogeneity between distinct intraracial populations (BEIGUELMAN, 1991). Genetic variability was estimated by the expected average heterozygosity, which is the mean of expected frequencies of heterozygotes at each locus calculated from HardyWeinberg equilibrium (He; NEI, 1987). The correction factor for the calculation of He suggested by NEI (1987) was used in the case of small sample sizes $(\mathrm{N}<50)$. Genetic distances (the differences between populations as expressed by gene frequencies) were estimated according to ROGERS (1972) and the dendrogram showing the patterns of genetic relationships between samples, based on genetic distances, was constructed using the Unweighted Pair Group Method Analysis, UPGMA (SNEATH \& SOKAL, 1973), by means of the BYOSIS program of SWOFFORD \& SELANDER (1981). The combined probabilities of paternity exclusion were estimated according to OISHI \& ABE (1970).

\section{RESULTS AND DISCUSSION}

Table 1 shows the gene frequencies of seven systems investigated in Piau and Caruncho pigs compared with those previously reported for Landrace, Large White, Duroc and the Brazilian Mouro breed (TAGLIARO et al., 1993; 1995) which were polymorphic for at least one of the breeds 


\begin{tabular}{|c|c|c|c|c|c|c|c|}
\hline \multirow[t]{2}{*}{ Locus } & \multirow[t]{2}{*}{ Allele } & \multicolumn{6}{|c|}{ Allele frequencies } \\
\hline & & $\begin{array}{l}\text { Piau } \\
(\mathrm{N}=57)\end{array}$ & $\begin{array}{c}\text { Caruncho } \\
(\mathrm{N}=7)\end{array}$ & $\begin{array}{l}\text { Mouro }^{1} \\
(\mathrm{~N}=58)\end{array}$ & $\begin{array}{l}\text { Landrace }^{2} \\
(\mathrm{~N}=109)\end{array}$ & $\begin{array}{l}\text { Large White }{ }^{2} \\
\quad(\mathrm{~N}=116)\end{array}$ & $\begin{array}{l}\text { Duroc }^{2} \\
(\mathrm{~N}=57)\end{array}$ \\
\hline \multirow[t]{2}{*}{ Pgd } & $\operatorname{Pgd}^{* A}$ & 0.711 & 1.000 & 0.853 & 0.628 & 0.621 & 0.228 \\
\hline & $\operatorname{Pgd} * B$ & 0.289 & 0.000 & 0.147 & 0.372 & 0.379 & 0.772 \\
\hline \multirow[t]{2}{*}{ EsD } & EsD*A & 0.666 & 1.000 & 0.647 & 0.931 & 1.000 & 0.851 \\
\hline & EsD*B & 0.334 & 0.000 & 0.353 & 0.069 & 0.000 & 0.149 \\
\hline \multirow[t]{3}{*}{ Amy1 } & Amy1*A & 0.070 & 0.000 & 0.000 & 0.133 & 0.090 & 0.000 \\
\hline & Amy $1 * B$ & 0.895 & 0.071 & 0.991 & 0.862 & 0.910 & 1.000 \\
\hline & Amy $1 * \mathrm{C}$ & 0.035 & 0.929 & 0.009 & 0.005 & 0.000 & 0.000 \\
\hline \multirow[t]{2}{*}{ Phi } & $\mathrm{Phi}^{*} \mathrm{~A}$ & 0.061 & 0.000 & 0.371 & 0.156 & 0.444 & 0.184 \\
\hline & Phi*B & 0.939 & 1.000 & 0.629 & 0.844 & 0.556 & 0.816 \\
\hline \multirow[t]{2}{*}{$\mathrm{Cp}$} & $\mathrm{Cp} * \mathrm{~A}$ & 0.000 & 0.000 & 0.000 & 0.018 & 0.000 & 0.000 \\
\hline & $\mathrm{Cp} * \mathrm{~B}$ & 1.000 & 1.000 & 1.000 & 0.982 & 1.000 & 1.000 \\
\hline \multirow[t]{4}{*}{ Hрx } & Hpx $* 0$ & 0.000 & 0.000 & 0.000 & 0.064 & 0.004 & 0.000 \\
\hline & Hрx*1 & 0.597 & 0.643 & 0.621 & 0.624 & 0.746 & 0.070 \\
\hline & $\mathrm{Hpx} * 2$ & 0.140 & 0.143 & 0.009 & 0.046 & 0.000 & 0.140 \\
\hline & Hрx*3 & 0.263 & 0.214 & 0.370 & 0.266 & 0.250 & 0.790 \\
\hline \multirow[t]{2}{*}{$\mathrm{Tf}$} & $\mathrm{Tf} * \mathrm{~A}$ & 0.000 & 0.071 & 0.172 & 0.037 & 0.168 & 0.096 \\
\hline & $\mathrm{Tf} * \mathrm{~B}$ & 1.000 & 0.929 & 0.828 & 0.963 & 0.832 & 0.904 \\
\hline
\end{tabular}

analysed. Ten of the fifteen loci were monomorphic in Piau (Mdh, Idh, Sod, Acp, Amy2, GloI, Al, Hb, Cp and $T f)$ and twelve in the Caruncho breed $(M d h, I d h$, Sod, Acp, Amy2, GloI, Al, Hb, Cp, Pgd, EsD and $P h i)$. Piau was the only breed monomorphic for $T f^{*} B$. In the Caruncho breed the absence of several alleles that are frequent in the other breeds examined $\left(P g d^{*} B, P h i^{*} A\right)$, may be explained by the small number of animals studied $(\mathrm{N}=7)$. The most frequent alleles observed in the Piau, Landrace, Large White and Mouro samples were $P g d^{*} A, E s D^{*} A, A m y l^{*} B$, $P h i * B$, and $H p x^{*} 1$. At polymorphic loci, the alleles $A m y{ }^{*} C, H p x^{*} l$ and $T f^{*} B$ were most frequent in the Caruncho breed. $A m y * C$ is an important marker for the Caruncho breed since it is the only one having this allele at a high frequency. The Piau and Caruncho animals showed a higher frequency of $P h i * B$ than that observed in the Landrace, Large White, Duroc and Mouro breeds. Allele $A m y^{*} A$, detected in Landrace and in Large White, was observed in Piau but not in Caruncho, and the $H p x * 0$ variant presented by the former two (European) breeds was not verified in either Piau or Caruncho.
The $C p^{*} A$ allele was only found in the Landrace population. $T f^{*} A$ was absent from the Piau breed only. In all systems, the observed distributions of phenotype frequencies were, as expected, according to Hardy-Weinberg equilibrium. Heterogeneity tests based on allelic distributions show that the Piau populations of Paraná and Minas Gerais were homogeneous, except for the EsD system (Yates corrected $\chi^{2}=9.54 ; \mathrm{P}=0.002$ ).

Considering all 15 loci, both monomorphic and polymorphic, the value obtained for expected average heterozygosity (He) was low for Caruncho $(\mathrm{He}=0,056)$. For Piau, He value was 0.114 , similar to that estimated previously for the other four breeds $\left(\mathrm{He}_{\text {Landrace }}=0.116 ; \mathrm{He}_{\text {Large }}\right.$ White $=0.119 ; \quad \mathrm{He}_{\text {Duroc }}=0.095 ; \mathrm{He}_{\text {Mouro }}=0.130$; TAGLIARO et al., 1993; 1995). Considering only the loci common to the different studies, the value of He of Piau was of the same order of magnitude to that computed for a wild population of East Balkanian Mountain Pig (VAN ZEVEREN et al., 1990) and for four other North American wild pig 
populations (SMITH et al., 1980). On the other hand, the Caruncho breed showed a lower $\mathrm{He}$ when compared with the wild pig populations mentioned above. Low He values can result from the loss of alleles due to the "founder effect" which is the establishment of a new population by a few original founders which carry only a small fraction of the total genetic variation of the parental population (RIDLEY, 1993). However, the low values of $\mathrm{He}$ observed for the Caruncho breed could be caused by bias as a consequence of the small number of ani-

mals sampled during the present study. As observed in previous studies involving Landrace, Large White, Duroc and Mouro breeds (TAGLIARO $\boldsymbol{e t} \boldsymbol{a l} ., 1993 ; 1995)$, the extent of genetic variability, at least at the loci investigated, does not seem to be affected by the selection methods commonly used by breeders. This also appears to be the case for the Piau breed investigated during the present study.

The theoretical probabilities of excluding paternity by one of two possible sires were calculated for the polymorphic systems, as well as the values of combined probability (table 2). For Piau and Caruncho breeds, the combined values obtained were $58 \%$ and $36 \%$, respectively. For the parental control tests, it is important to know which systems are the most informative for each population, since, as well as monomorphic loci, systems which exhibit low levels of variability are not useful in these analyses. Considering the 15 systems studied, for Piau the most efficient for the exclusion of paternity were $\mathrm{Hpx}(29,2 \%)$, EsD $(17,3 \%)$ and $\mathrm{Pgd}(16,3 \%)$; whereas for Caruncho, Hpx $(27,5 \%)$ also was informative. In previous reports, TAGLIARO et al. (1993; 1995) verified that $\mathrm{Hpx}$ and Pgd were efficient systems for paternity exclusion in Landrace, Large White and Duroc swine; and EsD was informative for paternity testing in Duroc and Mouro animals. The low value of probability obtained for Caruncho in part resulted from the fact that several systems are monomorphic for this breed (Pgd, EsD, Phi and $\mathrm{Cp}$ ) and also because of the low frequencies of some alleles due to the small sample size $\left(A m l^{*} B, T f^{*} A\right.$; see Table 1$)$. In the absence of exclusion, knowing the gene frequencies of the population and the genotypes of the pigs investigated, allow calculation of a paternity inclusion index (LEE, 1980).

Table 3 shows the genetic distance coefficients (D) between Piau, Caruncho and four other breeds reared in southern Brazil, calculated according to ROGERS (1972). According to these data, Caruncho was the most divergent from all the other five breeds, showing distances that range from 0.107 (with Landrace) to 0.176 (with Duroc). The closest distance was observed between Landrace and Piau $(\mathrm{D}=0.042)$.

The phenogram constructed from the genetic distances estimated according to ROGERS (1972) and using the UPGMA method show the genetic relationships between Piau, Caruncho and the remaining breeds (see figure 1). It was expected that all three Brazilian breeds join together, however, Piau and Mouro grouped with the European breeds (Landrace and Large White) whereas the Caruncho breed was isolated from all the others including the Brazilian Piau and Mouro. There was no relation between the main morphological features of each breed described in
Table 3 - Genetic distances among Piau and Caruncho and four other swine breeds reared in Brazil (x1000).

\begin{tabular}{llllll}
\hline Breed & Piau & Caruncho & Mouro & Landrace & Large White \\
\hline Caruncho & 111 & & & & \\
Mouro & 57 & 136 & & & \\
Landrace & 42 & 107 & 73 & & \\
Large White & 77 & 129 & 58 & 44 & 106 \\
Duroc & 100 & 176 & 107 & 84 & \\
\hline
\end{tabular}




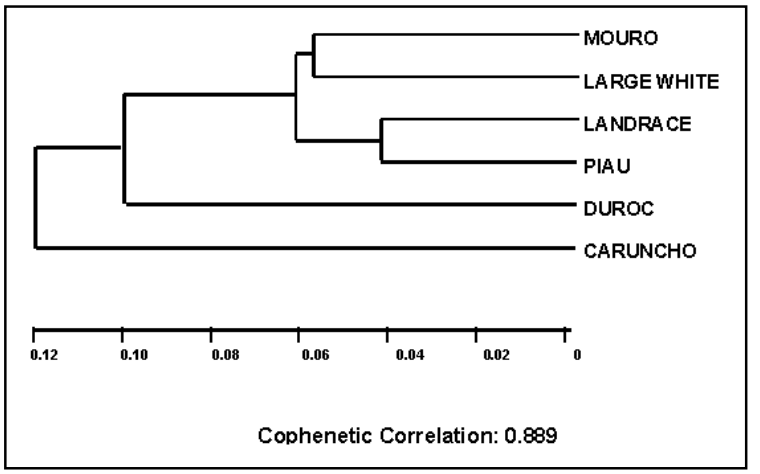

Figure 1 - Cluster analysis by UPGMA using Rogers' Distance Matrix (1972) calculated for six swine breeds.

the literature, such as coat color, skin color, size and shape of the head and ears (see SILVA, 1987; CAVALCANTI, 1984), and the topological arrangement obtained in the phylogenetic tree. The results suggest that the origin and development of the Caruncho were independent of those of the other two Brazilian breeds, but it is necessary to increase the sample number to decide if this is the case. On the other hand, stocks of Landrace and Large White may have been crossed with Mouro and Piau pigs.

\section{ACKNOWLEDGMENTS}

The authors are grateful to Dr. Simone Koproswki of the "Universidade Federal de Minas Gerais" for assistance in the collection of blood from pigs at the Professor Hélio Barbosa Experimental Farm, Minas Gerais, Brazil. We thank Dr. Colin R. Beasley for checking the English.

This study was financed by the "Conselho Nacional de Desenvolvimento Científico e Tecnológico (CNPq)", the "Fundacão de Amparo a Pesquisa do Estado do Rio Grande do Sul (FAPERGS)", and the "Financiadora de Estudos e Projetos (FINEP)".

\section{REFERENCES}

BARRETO, G.B. Curso de Suinocultura. 5.ed. Campinas: Instituto Campineiro de Ensino Agrícola, 1986. 595 p.

BEIGUELMAN, B. Curso Prático de Bioestatística. 2.ed Ribeirão Preto: Revista Brasileira de Genética, 1991. 231 p.

CAVAlCANTI, S.S. Produção de Suínos. Campinas: Instituto Campineiro de Ensino Agrícola, 1984. 453 p.

FRANCO, M.H.L.P., MOREIRA, D.M., SALZANO, F.M. et al. New data on the association between the GlioxalaseI and Haptoglobin loci. Hum Hered, v. 36, p. 126-128, 1986.

GAHNE, B., JUNEJA, R.K. Prediction of the halothane (Hal) genotypes of pigs by deducing $\mathrm{Hal}$, Phi, Po2, Pgd haplotypes of parents and offspring results from large scale prectice in Swedish breeds. Anim Blood Groups Biochem Genet, v. 16 p. 265-283, 1985 .

HARRIS, H., HOPKINSON, D.A. Handbook of Enzyme Electrophoresis in Human Genetics. Amsterdam: North Holland, 1976.

KRISTJANSSON, F.K. Genetic control of two pre-albumins in pigs. Genetics, v. 48, p. 1059-1063, 1963

LEE, C.L. Numerical expression of paternity test results using predetermined indexes. Am J Clin Pathol, v. 73, p. 522-536, 1980.
NAOUM, P.C. Diagnósticos das Hemoglobinopatias. São Paulo: Sarvier, 1987. 174 p.

NEI, M. Molecular Evolutionary Genetics. New York: Columbia University Press, 1987. 512 p.

OISHI, T., ABE, T. Studies on blood groups of pigs. VI. Usefulness of blood groups and serum protein types for parentage test. Jap J Zootech Sci, v. 41, n. 10, p. 501-506, 1970 .

OISHI, T., ESAKI, K., TOMITA, T. Genetic relationship among Gottingen Miniature, European and East Asian Pigs investigated from blood groups and biochemical polymorphism, Jap J Zootech Sci, v. 51, n. 3, p. 226-228, 1980.

OISHI, T., TOMITA, T. Blood groups and serum protein polymorphisms in the Pitman-Moore and Ohmini strain of miniature pigs. Anim Blood Groups Biochem Genet, v. 7, p. 27-32, 1976.

RIDLEY, M. Evolution. Oxford: Blackwell Scientific Publications, 1993. 670 p.

ROGERS, J.S. Measures of genetic similarity and genetic distance. Univ Texas Publ, v. 7213, p. 145-153, 1972.

SILVA, N.M. O Mouro no Brasil. Curitiba: Universidade Federal do Paraná, 1987. 24 p.

SMITH, C.A. Chi-squared tests with small numbers. Ann Hum Genet, v. 50, p. 163-167, 1986.

SMITH, M.W., SMITH, M.H., LEHR-BRISBIN-JR, I. Genetic variability and domestication in swine. J Mamm, v. 61, n. 1, p. $39-45,1980$.

SNEATH, P.H.A., SOKAL, R.R. Numerical Taxonomy. San Francisco: W. H. Freeman \& Company, 1973. 573 p.

SPENCER, N., HOPKINSON, D.A., HARRIS, H. Phosphoglucomutase polymorphism in man. Nature, v. 204, p. 742-745, 1964.

SWOFFORD, D.L., SELANDER, R.B. BIOSYS-1: A FORTRAN program for the comprehensive analysis of electrophoretic data in population genetics and systematics. J Hered, v. 72, p. 281-283, 1981.

TAGLIARO, C.H. FRANCO, M.H.L.P. , BRITO, B.G. Protein polymorphisms and genetic relationships in Mouro in relation to other breeds of pigs reared in southern Brazil. Braz J Genet, v. 18, n. 1, p. 69-73, 1995.

TAGLIARO, C.H., FRANCO, M.H.L.P., MEINCKE, W. Biochemical polymorphisms and genetic relationships among Landrace, Large White and Duroc pigs from Southern Brazil. Braz J Genet, v. 16, n. 3, p. 671-678, 1993.

TANAKA, K., OISHI, T., KUROSAWA, Y. et al. Genetic relationship among several pig populations in East Asia analysed by blood groups and serum protein polymorphisms. Anim Blood Groups Biochem Genet, v. 14, p. 191-200, 1983.

TUCKER, E.M. Serum albumin polymorphism in sheep. Vox Sang, v. 15 , p. $306-308,1968$.

VAN ZEVEREN, A., BOUQUET, Y., VAN DE WEGHE, A. $\boldsymbol{e}$ al. A genetic blood marker study on 4 pig breeds. I. Estimation and comparison of within breed variation. J Anim Breed Genet, v. 107, p. 104-112, 1990. 